\title{
Acaricomes phytoseiuli gen. nov., sp. nov., isolated from the predatory mite Phytoseiulus persimilis
}

\author{
Rüdiger Pukall, ${ }^{1}$ Peter Schumann, ${ }^{1}$ Conny Schütte, ${ }^{2}$ Rieta Gols ${ }^{2}$ \\ and Marcel Dicke ${ }^{2}$ \\ ${ }^{1}$ DSMZ - Deutsche Sammlung von Mikroorganismen und Zellkulturen, Mascheroder Weg 1b, \\ D-38124 Braunschweig, Germany \\ ${ }^{2}$ Laboratory of Entomology, Wageningen University, PO Box 8031, NL-6700 EH Wageningen, \\ The Netherlands
}

Correspondence

Rüdiger Pukall

rpu@dsmz.de

\begin{abstract}
A Gram-positive, rod-shaped, non-spore-forming bacterium, strain $\mathrm{CSC}^{\top}$, was isolated from diseased, surface-sterilized specimens of the predatory mite Phytoseiulus persimilis Athias-Henriot and subjected to polyphasic taxonomic analysis. Comparative analysis of the 16S rRNA gene sequence revealed that the strain was a new member of the family Micrococcaceae. Nearest phylogenetic neighbours were determined as Renibacterium salmoninarum (94.0\%), Arthrobacter globiformis (94.8\%) and Arthrobacter russicus (94.6\%). Although the predominant fatty acids (anteiso $\mathrm{C}_{15: 0}$ ), cell-wall sugars (galactose, glucose) and polar lipids (diphosphatidylglycerol, phosphatidylglycerol, phosphatidylinositol) are in accordance with those of members of the genus Arthrobacter, strain $\mathrm{CSC}^{\top}$ can be distinguished from members of the genus Arthrobacter by biochemical tests, the absence of a rod-coccus life cycle and the occurrence of the partially saturated menaquinone $\mathrm{MK}-10\left(\mathrm{H}_{2}\right)$ as the predominant menaquinone. The DNA G + C content is $57 \cdot 7 \mathrm{~mol} \%$. On the basis of morphological, chemotaxonomic and phylogenetic differences from other species of the Micrococcaceae, a novel genus and species are proposed, Acaricomes phytoseiuli gen. nov., sp. nov. The type strain is $\operatorname{CSC}^{\top}\left(=\mathrm{DSM} 14247^{\top}=\mathrm{CCUG}_{49701^{\top}}\right.$ ).
\end{abstract}

The mite Phytoseiulus persimilis Athias-Henriot is a specialized predator of spider mites in the genus Tetranychus and is one of the cornerstones of greenhouse biological control programmes against spider mites. A novel disease was detected in adult females of $P$. persimilis, the 'nonresponding syndrome' (Schütte et al., 1998; Dicke et al., 2000; Bjørnson \& Schütte, 2003), that significantly affected various characteristics of the predators that are important for successful biological control of spider mites. The disease was not transmitted vertically from mother to offspring directly via the egg, but was transmitted horizontally among and between generations via leftovers, e.g. faeces and debris of diseased mites (Schütte et al., 1998; C. Schütte and others, unpublished data).

Strain CSC $^{\mathrm{T}}$ was isolated from diseased surface-sterilized female $P$. persimilis mites on LB agar (Difco), incubated for 1 week under aerobic conditions at $25^{\circ} \mathrm{C}$. For observation of

Published online ahead of print on 28 October 2005 as DOI 10.1099/ ijs.0.63930-0.

The GenBank/EMBL/DDBJ accession number for the 16S rRNA gene sequence of strain CSC $^{\top}$ is AJ812213. colony and cell morphology, the strain was grown on tryptic soy agar (TSA; Difco) for 5 days at $25^{\circ} \mathrm{C}$. The oxidase test and determination of catalase activity were performed with reagent droppers (Becton Dickinson) according to the manufacturer's instructions. The temperature range for growth was determined by incubating inoculated slant agar cultures (TSA, pH. 7.0) at 4, 10, 15, 22, 25, 28, 30 and $37^{\circ} \mathrm{C}$. Growth was also assessed in tryptic soy broth (TSB; Difco) at pH $4 \cdot 5-$ $9 \cdot 5$. The lower $\mathrm{pH}$ values of the test medium were obtained by adding hydrochloric acid and $\mathrm{pH}$ values greater than $7 \cdot 5$ by addition of sterilized sodium sesquicarbonate buffer (1 M). Starch hydrolysis was tested by the standard procedure described by Collins et al. (1989); the agar plate was flooded with dilute iodine solution after 5 days of incubation.

The ability to utilize a variety of substrates as carbon sources was tested using the GP2 microplates of the MicroLog system (Biolog). Analyses were done in duplicate, in order to check the reproducibility of the results obtained. Bacterial cells were suspended in inoculating fluid (GP; Biolog) at the recommended cell density of $20 \%$ transmission using the Biolog turbidimeter. One hundred and fifty microlitres of the resulting solution was transferred to each well of the GP2 microplate and, after $24 \mathrm{~h}$ incubation at $30^{\circ} \mathrm{C}$, reduction of 
the tetrazolium dye was determined using the Microplate reader of the Biolog MicroStation.

For phylogenetic analysis, genomic DNA was extracted from bacteria and purified as described previously (Pukall et al., 1998). The primer pair $27 \mathrm{f}$ ( $5^{\prime}$-GAGTTTGATCCTGGCTCAG-3') and 1527r ( $5^{\prime}$-AGAAAGGAGGTGATCCAGCC-3') was used for amplification of the 16S rRNA gene (Lane, 1991). PCR amplification was done as described earlier (Pukall et al., 1999). Amplicons were sequenced by using the dye-labelled dideoxy-terminator cycle sequencing (DTCS) Quick Start kit and the Ceq8000 Genetic Analysis System from Beckman Coulter. The sequence was manually aligned and compared with published sequences from the DSMZ $16 \mathrm{~S}$ rRNA gene database, including sequences available from the Ribosomal Database Project (Maidak et al., 2001) and EMBL. A manual alignment was constructed with the BioEdit program (Hall, 1999) and used to calculate the distance matrix corrected by the Kimura 2-parameter method (Kimura, 1980). A phylogenetic dendrogram was inferred using the neighbour-joining method and CLUSTAL X (Thompson et al., 1997). Bootstrap analysis was based on 1000 resamplings.

Isolation of DNA (Cashion et al., 1977) for determination of the DNA G + C content by HPLC (Mesbah et al., 1989) followed described procedures. $\mathrm{G}+\mathrm{C}$ content of the DNA was calculated from six individual measurements.

Fatty acids were determined from cells freshly grown in TSB. Fatty acid methyl esters were obtained from freeze-dried biomass (approx. $10 \mathrm{mg}$ ) by saponification, methylation and extraction using the modifications (Kuykendall et al., 1988) of the method of Miller (1982). The fatty acids were separated using the 5898A Microbial Identification System (MIDI) as described previously (Pukall et al., 2003).

Isoprenoid quinones were extracted from strain $\mathrm{CSC}^{\mathrm{T}}$ grown in TSB, as described by Collins (1985). Analysis was performed by HPLC (Groth et al., 1996) and the menaquinone structure was determined by electron impact-mass spectrometry using a QP 2000 mass spectrometer fitted with a direct sample inlet device (Shimadzu) as described by Collins (1994). Analysis of the peptidoglycan structure was carried out as described by Schleifer (1985) and Schleifer \& Kandler (1972) with the modification that TLC on cellulose was applied instead of paper chromatography. Cell-wall sugars were analysed by using a modification of the method of Staneck \& Roberts (1974). Polar lipids extracted by the method of Minnikin et al. (1979) were identified by two-dimensional TLC and spraying with specific reagents (Collins \& Jones, 1980).

On TSA, smooth, circular, yellowish colonies were formed, 1-2 $\mathrm{mm}$ in diameter. Cell morphology of a culture grown in TSB was analysed microscopically using a phase-contrast microscope (Zeiss Axioplot). Cells were small, short rods, $0 \cdot 5-0 \cdot 8 \times 1-1.5 \mu \mathrm{m}$ in size. The optimal growth temperature was $25^{\circ} \mathrm{C}$. Growth was observed between 15 and $30^{\circ} \mathrm{C}$ and no growth occurred at 4,10 or $37^{\circ} \mathrm{C}$. Strain $\operatorname{CSC}^{\mathrm{T}}$ was able to grow in TSB at initial $\mathrm{pH}$ values ranging from $\mathrm{pH} 6 \cdot 0$ to $9 \cdot 5$, with an optimum range of $\mathrm{pH} 6 \cdot 0-8 \cdot 0$. A rod-coccus life cycle, typical of members of the genus Arthrobacter, could not be observed during 3 days of incubation. The oxidase test was negative, but catalase activity was detectable. Detailed characteristics obtained from the Biolog GP2 assay after 3 days of incubation at $25^{\circ} \mathrm{C}$ are indicated in the species description.

The nearest phylogenetic neighbours, determined by analysis of the nearly complete $16 \mathrm{~S}$ rRNA gene sequence, were found to be members of the family Micrococcaceae. Highest sequence similarities were obtained for Renibacterium salmoninarum (94.0\%), Arthrobacter globiformis (94.8\%) and Arthrobacter russicus (94.6\%). Patterns of selected $16 \mathrm{~S}$ rRNA gene signature nucleotides defined for the family Micrococcaceae (Stackebrandt et al., 1997; Stackebrandt \& Schumann, 2000) were consistent with nucleotides determined for the 16S rRNA gene sequence of strain $\operatorname{CSC}^{\mathrm{T}}$. Positions $502-543$ and $1310-1327$, given as $\mathrm{R}-\mathrm{Y}$ by Stackebrandt \& Schumann (2000), were determined as A$\mathrm{U}$ and $\mathrm{G}-\mathrm{C}$, respectively. The position of strain $\mathrm{CSC}^{\mathrm{T}}$ relative to its phylogenetic neighbours is shown in Fig. 1.

The sequences of the type strains of Arthrobacter viscosus and Arthrobacter siderocapsulatus were not included in the phylogenetic analysis, because these two species can not be considered to be authentic members of the genus Arthrobacter (Stackebrandt \& Schumann, 2000). The sequence of the type strain of Arthrobacter viscosus clustered with Rhizobium species and Arthrobacter siderocapsulatus was reported to be a later heterotypic synonym of Pseudomonas putida (Chun et al., 2001). The type strain of Arthrobacter ramosus (CCM 1646 ${ }^{\mathrm{T}}$ ) was obtained from the Czechoslovak Collection of Microorganisms in 2004 and used for reanalysis of its 16S rRNA gene sequence.

Cellular fatty acid analysis revealed predominant amounts of the branched fatty acids anteiso- $\mathrm{C}_{15: 0}(53 \cdot 59 \%)$ and anteiso- $\mathrm{C}_{17: 0}(31 \cdot 90 \%)$. iso- $\mathrm{C}_{16: 0}(6 \cdot 28 \%), \mathrm{C}_{16: 0}(3 \cdot 62 \%)$ and iso- $\mathrm{C}_{15: 0}(1 \cdot 71 \%)$ were detectable in smaller amounts.

The peptidoglycan contained the amino acids lysine, alanine and glutamic acid in the molar ratio of $1 \cdot 0: 4 \cdot 9: 1 \cdot 0$. Twodimensional TLC of the partial hydrolysate revealed the presence of peptides characteristic of interpeptide bridges consisting of several L-Ala residues. Strain $\mathrm{CSC}^{\mathrm{T}}$ possesses peptidoglycan of type $\mathrm{A} 3 \alpha$, L-Lys-L-Ala 3 (type A11.6 according to the DSMZ catalogue of strains; also available at http://www.dsmz.de/species/murein.htm). Cell-wall sugars consisted of galactose and glucose. Phosphatidylinositol (PI), phosphatidylglycerol (PG) and diphosphatidylglycerol (DPG) were found as polar lipids.

Strain $\operatorname{CSC}^{\mathrm{T}}$ contained the partially saturated menaquinones MK-10 $\left(\mathrm{H}_{2}\right)$, MK-11 $\left(\mathrm{H}_{2}\right)$, MK-9 $\left(\mathrm{H}_{2}\right)$ and MK-8 $\left(\mathrm{H}_{2}\right)$ with the ratio of HPLC peak areas of $61: 11: 8: 7$. The electron impact mass spectrum of the major component 


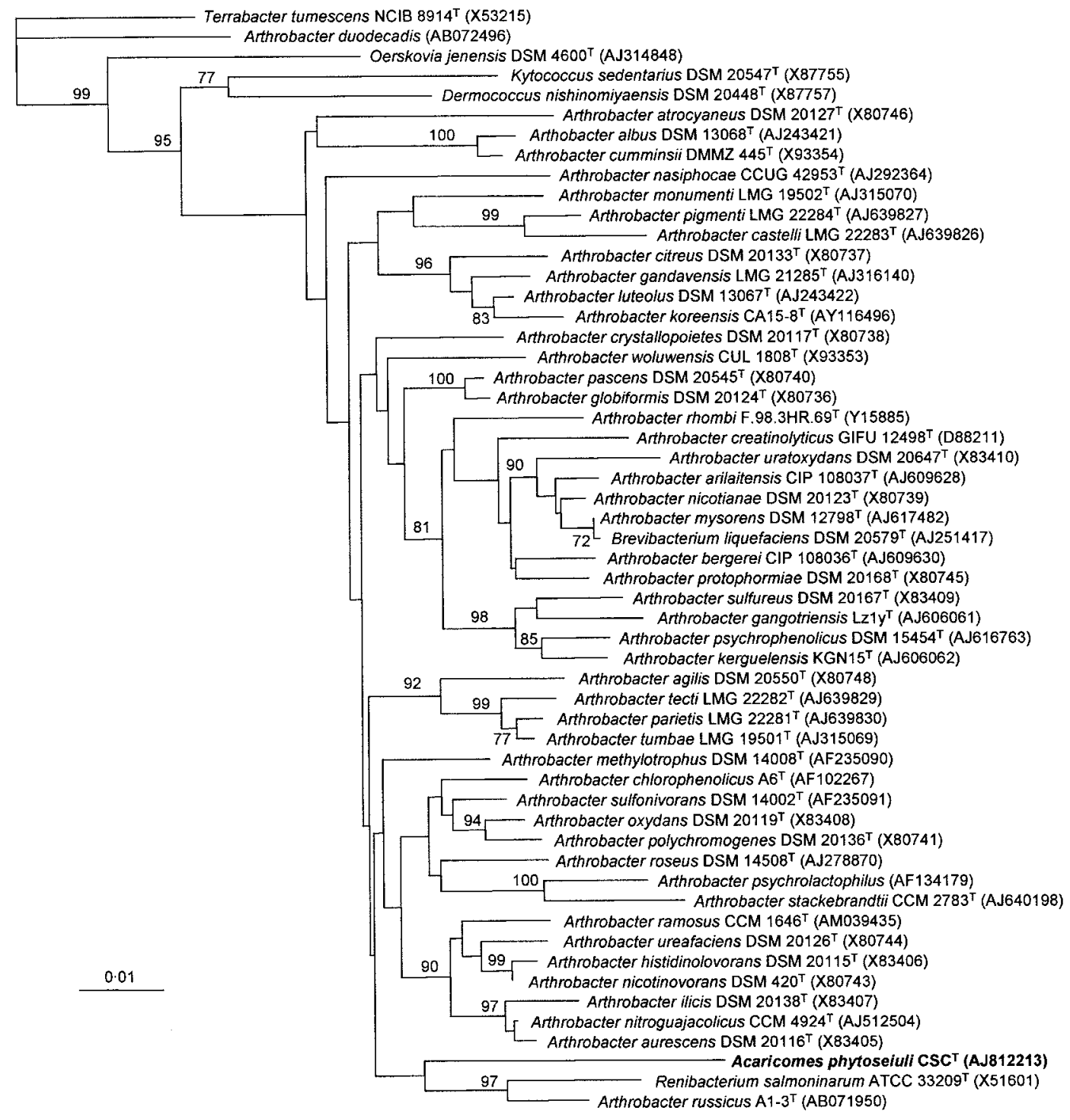

Fig. 1. Neighbour-joining tree based on nearly complete 16S rRNA gene sequences showing the phylogenetic position of strain $\mathrm{CSC}^{\top}$ among members of the family Micrococcaceae, suborder Micrococcineae (Stackebrandt et al., 1997). Bootstrap values (percentages of 1000 replications) greater than $70 \%$ are shown at branching points. Bar, 1 substitution per 100 nucleotide positions. Note that Brevibacterium liquefaciens is a heterotypic synonym of Arthrobacter nicotianae (Gelsomino et al., 2004).

revealed the additional presence of an isoprenoid quinone methylated at the aromatic nucleus. From the fragment ions detected it was concluded that, in addition to MK- $10\left(\mathrm{H}_{2}\right)$, MMK-10 $\left(\mathrm{H}_{2}\right)$ also occurred. The $\mathrm{G}+\mathrm{C}$ content of the DNA was $57 \cdot 7 \pm 0 \cdot 5 \mathrm{~mol} \%$.

Characteristics that differentiate strain $\mathrm{CSC}^{\mathrm{T}}$ from other representatives of the nearest phylogenetic neighbours detected by 16S rRNA gene sequence analysis are given in Table 1. 16S rRNA gene sequence analysis, chemotaxonomic properties and the profile of metabolic properties revealed that strain $\operatorname{CSC}^{\mathrm{T}}$ represents a new genus and a novel species within the family of Micrococcaceae, for which the name Acaricomes phytoseiuli gen. nov., sp. nov. is proposed.

\section{Description of Acaricomes gen. nov.}

Acaricomes (A.ca.ri.co'mes. N.L. masc. pl. n. acari the mites; L. masc. n. comes companion; N.L. masc. n. Acaricomes companion of mites).

Gram-positive, aerobic, non-endospore-forming rods. A rod-coccus life cycle is absent. Mesophilic. The pH optimum for growth is $\mathrm{pH} 6 \cdot 0-8 \cdot 0$. Catalase-positive, oxidasenegative. The peptidoglycan type is A $3 \alpha \mathrm{L}-\mathrm{Lys}-\mathrm{L}-\mathrm{Ala}_{3}$. The 
Table 1. Comparison of properties of Acaricomes phytoseiuli $\mathrm{CSC}^{\top}$ and its nearest phylogenetic neighbours

Strains/species: 1, Acaricomes phytoseiuli $\mathrm{CSC}^{\mathrm{T}}$; 2, Arthrobacter globiformis (unless indicated, data from Keddie et al., 1986); 3, Arthrobacter russicus $\mathrm{A} 1-3^{\mathrm{T}}$ (Li et al., 2004); 4, Renibacterium salmoninarum Lea-1-74 ${ }^{\mathrm{T}}$ (Sanders \& Fryer, 1980). +, Positive, -, negative; W, weak reaction, NA, data not available.

\begin{tabular}{|c|c|c|c|c|}
\hline Characteristic & 1 & 2 & 3 & 4 \\
\hline Colony colour & Yellow & Cream/white & Cream/white & Cream/white to yellow \\
\hline Cell morphology & Short rods & Irregular rods, cocci & Irregular rods & Short rods \\
\hline Rod-coccus cycle & - & + & NA & - \\
\hline Cell-wall sugars ${ }^{\star}$ & Gal, Glc & Gal, Glc & NA & Gal, Rha \\
\hline Peptidoglycan type & L-Lys--Ala 3 & L-Lys- $-\mathrm{Ala}_{3}$ & L-Lys-Ala ${ }_{2}$ & L-Lys-Ala-Gly \\
\hline Predominant menaquinone & MK-10 $\left(\mathrm{H}_{2}\right)$ & MK-9 $\left(\mathrm{H}_{2}\right)$ & MK-9 $\left(\mathrm{H}_{2}\right)$ & MK-9 \\
\hline Hydrolysis of starch & $-\dagger$ & + & NA & $\mathrm{NA}$ \\
\hline DNA G $+C$ content $(\mathrm{mol} \%)$ & $57 \cdot 7$ & $61-66$ & $65 \cdot 5$ & $52-54$ \\
\hline \multicolumn{5}{|l|}{ Utilization of: $¥$} \\
\hline Dextrin & + & + & - & NA \\
\hline Maltose & + & + & - & NA \\
\hline Maltotriose & + & + & - & NA \\
\hline D-Mannitol & - & + & - & NA \\
\hline$\alpha$-Hydroxybutyric acid & - & + & - & NA \\
\hline Uridine & - & + & + & NA \\
\hline Xylose & - & + & - & NA \\
\hline L-Glutamic acid & + & $\mathrm{W}$ & $\mathrm{W}$ & NA \\
\hline Glucose 1-phosphate & + & - & - & NA \\
\hline
\end{tabular}

${ }^{*}$ Gal, Galactose; Glc, glucose; Rha, rhamnose.

$\dagger$ Test performed according to Collins et al. (1989).

¥Biolog GP2 assay data for Arthrobacter globiformis are for strain DSM $20124^{\mathrm{T}}$ and were obtained in this study.

predominant menaquinone is the partially saturated menaquinone $\mathrm{MK}-10\left(\mathrm{H}_{2}\right)$ with one of the ten isoprene units hydrogenated; in addition, MMK-10 $\left(\mathrm{H}_{2}\right)$ is detectable. The main fatty acids determined are anteiso- $\mathrm{C}_{15: 0}$ (12methyltetradecanoic acid) and anteiso- $\mathrm{C}_{17: 0}$ (14-methylhexadecanoic acid). The major polar lipids are PG, DPG and PI. The type species is Acaricomes phytoseiuli.

\section{Description of Acaricomes phytoseiuli sp. nov.}

Acaricomes phytoseiuli (phy.to.sei'u.li. N.L. gen. masc. n. phytoseiuli of Phytoseiulus, the nomenclatural genus name of the host mite).

Shows the following properties in addition to those given in the genus description. Cells are $0 \cdot 5-0 \cdot 8 \times 1-1 \cdot 5 \mu \mathrm{m}$ in size. Colonies on TSA are circular, convex, $1-2 \mathrm{~mm}$ in diameter and coloured yellowish. Growth occurs at $15-$ $30^{\circ} \mathrm{C}$ with an optimum of $25^{\circ} \mathrm{C}$. Grows at pH 6.0-9.5. Utilizes dextrin, $\alpha$-D-glucose, $\alpha$-D-fructose, maltose, maltotriose, D-mannose, sucrose, turanose, L-glutamic acid and glucose 1-phosphate. Only weak reactions for utilization of Tween 80, palatinose, L-pyroglutamic acid and glucose 6-phosphate. The following substrates are not utilized: $\alpha$ - and $\beta$-cyclodextrin, glycogen, inulin, mannan, Tween 40 , $\mathrm{N}$-acetyl-D-glucosamine, $\mathrm{N}$-acetyl-D-mannosamine, amygdalin, L-arabinose, D-arabitol, arbutin, D-cellobiose, L-fucose, D-galactose, D-galacturonic acid, gentiobiose, D-gluconic acid, myo-inositol, $\alpha$-D-lactose, lactulose, D-mannitol, Dmelezitose, D-melibiose, methyl $\alpha$-D-galactoside, methyl $\beta$-D-galactoside, 3 -methyl glucose, methyl $\alpha$-glucoside, methyl $\beta$-D-glucoside, methyl $\alpha$-D-mannoside, D-psicose, D-raffinose, L-rhamnose, D-ribose, salicin, sedoheptulosan, D-sorbitol, stachyose, D-tagatose, D-trehalose, xylitol, Dxylose, acetic acid, $\alpha$-, $\beta$ - and $\gamma$-hydroxybutyric acid, $p$ hydroxyphenylacetic acid, $\alpha$-ketovaleric acid, lactamide, D-lactic acid methyl ester, L-lactic acid, D-malic acid, methylpyruvate, monomethyl succinate, propionic acid, pyruvic acid, succinamic acid, succinic acid, $\mathrm{N}$-acetyl-Lglutamic acid, L-alaninamide, D-alanine, L-alanyl glycine, glycyl L-glutamic acid, L-serine, putrescine, 2,3-butanediol, glycerol, adenosine, 2' -deoxyadenosine, inosine, thymidine, uridine, adenosine $5^{\prime}$-monophosphate, thymidine $5^{\prime}$ monophosphate, uridine $5^{\prime}$-monophosphate, fructose 6phosphate and DL- $\alpha$-glycerol phosphate. Cell-wall sugars are galactose and glucose. The $\mathrm{G}+\mathrm{C}$ content of the type strain is $57 \cdot 7 \mathrm{~mol} \%$.

The type strain, $\operatorname{CSC}^{\mathrm{T}}\left(=\mathrm{DSM} 14247^{\mathrm{T}}=\right.$ CCUG $\left.49701^{\mathrm{T}}\right)$, was isolated from the predatory mite Phytoseiulus persimilis.

\section{Acknowledgements}

This work was partially funded by the Technology Foundation (STW), grant WBI.4573 to C.S., R. G. and M.D. 


\section{References}

Bjørnson, S. \& Schütte, C. (2003). Pathogens of mass-produced natural enemies and pollinators. In Quality Control and Production of Biological Control Agents - Theory and Testing Procedures, pp. 133-165. Edited by J. C. Van Lenteren. Wallingford, UK: CAB International.

Cashion, P., Holder-Franklin, M. A., McCully, J. \& Franklin, M. (1977). A rapid method for the base ratio determination of bacterial DNA. Anal Biochem 81, 461-466.

Chun, J., Rhee, M. S., Han, J. I. \& Bae, K. S. (2001). Arthrobacter siderocapsulatus Dubinina and Zhdanov $1975^{\mathrm{AL}}$ is a later subjective synonym of Pseudomonas putida (Trevisan 1889) Migula $1895^{\mathrm{AL}}$. Int J Syst Evol Microbiol 51, 169-170.

Collins, M. D. (1985). Isoprenoid quinone analyses in bacterial classification and identification. In Chemical Methods in Bacterial Systematics, pp. 267-287. Edited by M. Goodfellow \& D. E. Minnikin, London: Academic Press.

Collins, M. D. (1994). Isoprenoid quinones. In Chemical Methods in Prokaryotic Systematics, pp. 265-305. Edited by M. Goodfellow \& A. G. O'Donnell, Chichester: Wiley.

Collins, M. D. \& Jones, D. (1980). Lipids in the classification and identification of coryneform bacteria containing peptidoglycans based on 2,4-diaminobutyric acid. J Appl Bacteriol 48, 459-470.

Collins, C. H., Lyne, P. M. \& Grange, J. M. (1989). Identification methods. In Microbiological Methods, 6th edn, pp. 96-114. London: Butterworth.

Dicke, M., Schütte, C. \& Dijkman, H. (2000). Change in behavioral response to herbivore-induced plant volatiles in a predatory mite population. J Chem Ecol 26, 1497-1514.

Gelsomino, R., Vancanneyt, M. \& Swings, J. (2004). Reclassification of Brevibacterium liquefaciens Okabayashi and Masuo 1960 as Arthrobacter nicotianae Giovannozzi-Sermanni 1959. Int J Syst Evol Microbiol 54, 615-616.

Groth, I., Schumann, P., Weiss, N., Martin, K. \& Rainey, F. A. (1996). Agrococcus jenensis gen. nov., sp. nov., a new genus of actinomycetes with diaminobutyric acid in the cell wall. Int J Syst Bacteriol 46, 234-239.

Hall, T. A. (1999). BioEdit: a user-friendly biological sequence alignment editor and analysis program for Windows 95/98/NT. Nucleic Acids Symp Ser 41, 95-98.

Keddie, R. M., Collins, M. D. \& Jones, D. (1986). Genus Arthrobacter Conn and Dimmick 1947, 300 ${ }^{\mathrm{AL}}$. In Bergey's Manual of Systematic Bacteriology, vol. 2, pp. 1288-1301. Edited by P. H. A. Sneath, N. S. Mair, M. E. Sharpe \& J. G. Holt. Baltimore: Williams \& Wilkins.

Kimura, M. (1980). A simple method for estimating evolutionary rates of base substitutions through comparative studies of nucleotide sequences. J Mol Evol 16, 111-120.

Kuykendall, L. D., Roy, M. A., O'Neill, J. J. \& Devine, T. E. (1988). Fatty acids, antibiotic resistance, and deoxyribonucleic acid homology groups of Bradyrhizobium japonicum. Int J Syst Bacteriol 38, 358-361.

Lane, D. J. (1991). 16S-23S rRNA sequencing. In Nucleic Acid Techniques in Bacterial Systematics, pp. 125-175. Edited by E. Stackebrandt \& M. Goodfellow. Chichester: Wiley.

Li, Y., Kawamura, Y., Fujiwara, N., Naka, T., Liu, H., Huang, X., Kobayashi, K. \& Ezaki, T. (2004). Rothia aeria sp. nov., Rhodococcus baikonurensis sp. nov. and Arthrobacter russicus sp. nov., isolated from air in the Russian space laboratory Mir. Int J Syst Evol Microbiol 54, 827-835.

Maidak, B. L., Cole, J. R., Lilburn, T. G. \& 7 other authors (2001). The RDP-II (Ribosomal Database Project). Nucleic Acids Res 29, 173-174.

Mesbah, M., Premachandran, U. \& Whitman, W. B. (1989). Precise measurement of the $\mathrm{G}+\mathrm{C}$ content of deoxyribonucleic acid by high-performance liquid chromatography. Int J Syst Bacteriol 39, 159-167.

Miller, L. T. (1982). A single derivatization method for bacterial fatty acid methyl esters including hydroxy acids. J Clin Microbiol 16, 584-586.

Minnikin, D. E., Collins, M. D. \& Goodfellow, M. (1979). Fatty acid and polar lipid composition in the classification of Cellulomonas, Oerskovia and related taxa. J Appl Bacteriol 47, 87-95.

Pukall, R., Brambilla, E. \& Stackebrandt, E. (1998). Automated fragment length analysis of fluorescently-labeled 16S rDNA after digestion with 4-base cutting restriction enzymes. J Microbiol Methods 32, 55-64.

Pukall, R., Buntefuß, D., Frühling, A., Rohde, M., Kroppenstedt, R. M., Burghardt, J., Lebaron, P., Bernard, L. \& Stackebrandt, E. (1999). Sulfitobacter mediterraneus sp. nov., a new sulfite-oxidizing member of the $\alpha$-Proteobacteria. Int J Syst Bacteriol 49, 513-519.

Pukall, R., Laroche, M., Kroppenstedt, R. M., Schumann, P., Stackebrandt, E. \& Ulber, R. (2003). Paracoccus seriniphilus sp. nov., an L-serine-dehydratase-producing coccus isolated from the marine bryozoan Bugula plumosa. Int J Syst Evol Microbiol 53, 443-447.

Sanders, J. E. \& Fryer, J. L. (1980). Renibacterium salmoninarum gen. nov., sp. nov., the causative agent of bacterial kidney disease in salmonid fishes. Int J Syst Bacteriol 30, 496-502.

Schleifer, K. H. (1985). Analysis of the chemical composition and primary structure of murein. Methods Microbiol 18, 123-156.

Schleifer, K. H. \& Kandler, O. (1972). Peptidoglycan types of bacterial cell walls and their taxonomic implications. Bacteriol Rev 36, 407-477.

Schütte, C., Van Baarlen, P., Dijkman, H. \& Dicke, M. (1998). Change in foraging behaviour of the predatory mite Phytoseiulus persimilis after exposure to dead conspecifics and their products. Entomol Exp Appl 88, 295-300.

Stackebrandt, E. \& Schumann, P. (2000). Introduction to the taxonomy of Actinobacteria. In The Prokaryotes: an Evolving Electronic Resource for the Microbiological Community, 3rd edn, release 3.3, 9 September 2000. Edited by M. Dworkin et al. New York: Springer. http://link.springer-ny.com/link/service/books/10125/

Stackebrandt, E., Rainey, F. A. \& Ward-Rainey, N. L. (1997). Proposal for a new hierarchic classification system, Actinobacteria classis nov. Int J Syst Bacteriol 47, 479-491.

Staneck, J. L. \& Roberts, G. D. (1974). Simplified approach to identification of aerobic actinomycetes by thin layer chromatography. Appl Microbiol 28, 226-231.

Thompson, J. D., Gibson, T. J., Plewniak, F., Jeanmougin, F. \& Higgins, D. G. (1997). The CLUSTAL_X windows interface: flexible strategies for multiple sequence alignment aided by quality analysis tools. Nucleic Acids Res 25, 4876-4882. 